\title{
Radiolytic Treatment of the
}

\section{Next-Generation Caustic-Side Solvent Extraction (NGS) Solvent and its Effect on the NGS Process}

Benjamin D. Roach, Neil J. Williams, Nathan C. Duncan, Lætitia H. Delmau, Denise L. Lee, Joseph F. Birdwell, Jr., and Bruce A. Moyer

Oak Ridge National Laboratory (ORNL), Oak Ridge, TN, USA 37830

Supplementary Information

INTRODUCTION

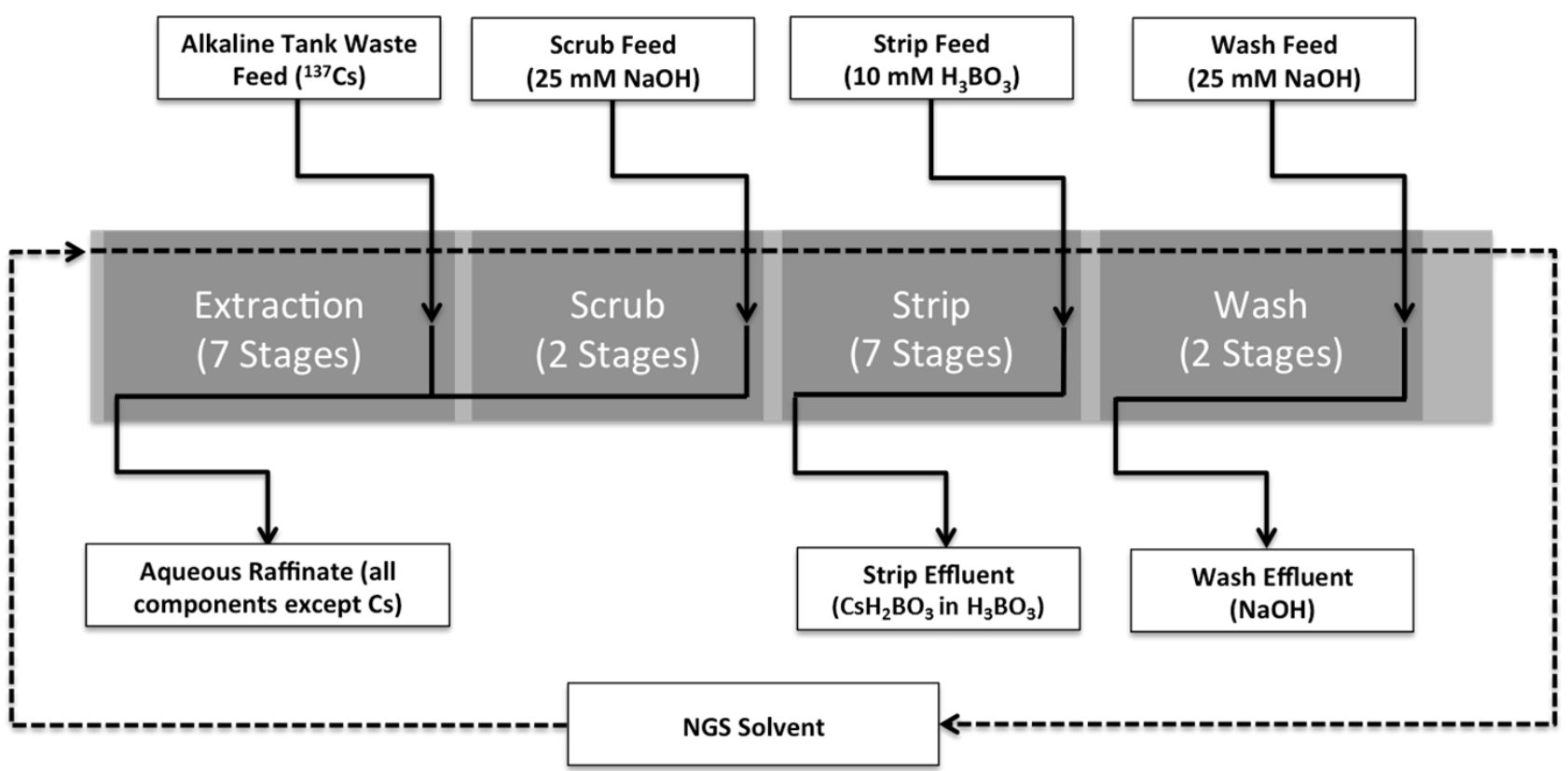

Figure 1: NGS Flowsheet for the Modular CSSX Unit (MCU) at Savannah River Site (SRS). ${ }^{[1]}$ 


\section{Supplementary Information}

\section{EXPREIMENTAL}

Table 1. Constituent ions of the tank waste simulant SRS-15 $5^{[2]}$

\begin{tabular}{|c|c|}
\hline Analyte or Species & $\begin{array}{c}\text { SRS-15 } \\
\mathrm{mol} / \mathrm{L}\end{array}$ \\
\hline \multicolumn{2}{|l|}{ Principal constituents: } \\
\hline $\mathrm{Al}$ as $\left(\mathrm{Al}(\mathrm{OH})_{4}^{-}\right)$ & 0.280 \\
\hline $\mathrm{Cl}^{-}$ & $2.4 \times 10^{-2}$ \\
\hline $\mathrm{CO}_{3}^{2-}(\mathrm{TIC})$ & 0.150 \\
\hline $\mathrm{Cs}^{+}$(Total) & $1.4 \times 10^{-4}$ \\
\hline $\mathrm{K}^{+}$ & 0.015 \\
\hline $\mathrm{Na}^{+}$ & 5.60 \\
\hline $\mathrm{NO}_{2}{ }^{-}$ & 0.500 \\
\hline $\mathrm{NO}_{3}^{-}$ & 2.03 \\
\hline $\mathrm{OH}^{-}$(Free) & 2.06 \\
\hline $\mathrm{SO}_{4}^{2-}$ & 0.140 \\
\hline
\end{tabular}

Minor inorganic constituents:

\begin{tabular}{rl}
$\mathrm{Ag}(\mathrm{I})$ & $9.3 \times 10^{-8}$ \\
$\mathrm{CrO}_{4}{ }^{2-}$ & $1.4 \times 10^{-3}$ \\
$\mathrm{Cu}(\mathrm{II})$ & $2.3 \times 10^{-5}$ \\
$\mathrm{~F}^{-}$ & $2.8 \times 10^{-2}$ \\
$\mathrm{Fe}(\mathrm{III})$ & $2.6 \times 10^{-5}$ \\
$\mathrm{Hg}(\mathrm{II})$ & $2.5 \times 10^{-7}$ \\
$\mathrm{MoO}_{4}{ }^{2-}$ & $7.0 \times 10^{-5}$ \\
$\mathrm{NH}_{3}$ & $1.0 \times 10^{-3}$ \\
$\mathrm{~Pb}(\mathrm{II})^{-5}$ & $1.0 \times 10^{-5}$ \\
$\mathrm{Pd}(\mathrm{II})^{3-}$ & $3.8 \times 10^{-6}$ \\
$\mathrm{PO}{ }^{3-}$ & $7.0 \times 10^{-3}$ \\
$\mathrm{Rh}(\mathrm{III})$ & $2.0 \times 10^{-6}$ \\
$\mathrm{Ru}(\mathrm{III})$ & $8.1 \times 10^{-6}$ \\
$\mathrm{Si}(\mathrm{IV})$ & $3.0 \times 10^{-2}$ \\
$\mathrm{Sn}(\mathrm{II})$ & $2.0 \times 10^{-5}$ \\
\hline
\end{tabular}

Minor organic constituents:

n-Butanol

$2.7 \times 10^{-5}$

Tri- $n$-butylphosphate (TBP)

$1.9 \times 10^{-6}$

Di- $n$-butylphosphate (DBP)

$1.2 \times 10^{-4}$ 


\section{Supplementary Information}

Mono- $n$-butylphosphate (MBP)

Formate $\left(\mathrm{HCO}_{2}{ }^{-}\right)$

Oxalate $\left(\mathrm{C}_{2} \mathrm{O}_{4}{ }^{2-}\right)$

Trimethylamine
$1.6 \times 10^{-4}$

$3.3 \times 10^{-2}$

$8.0 \times 10^{-3}$

$1.7 \times 10^{-4}$

\section{Absorbed Dose Calculation.}

The original activity of the ${ }^{60} \mathrm{Co}$ source was $24,000 \mathrm{Ci}$ in 1977 . At the time of installation, the dose rate $\left(D_{0}\right)$ was determined to be $18,500 \mathrm{~Gy} / \mathrm{h}$. The half-life $\left(t_{1 / 2}\right)$ of ${ }^{60} \mathrm{Co}$ is $5.27 \mathrm{y}$, which is used to calculate the current dose rate. Using Eq. 1, Samples were analyzed at 2500, 5000, $10,000,25,000$, and 50,000 Gy. The length of irradiations was calculated by simply dividing the desired dose by the dose rate, $R$.

$$
R=R_{0} e^{-0.693 t / t_{1 / 2}}
$$

Table 2. Defined doses and calculated exposure times

\begin{tabular}{llllll}
\hline Dose (kGy) & 2.5 & 5 & 10 & 25 & 50 \\
\hline Contact duration $(\mathrm{h})$ & 11 & 22 & 44 & 110 & 220 \\
\hline
\end{tabular}

\section{Gas Chromatography Machine Settings}

For the 6850/FID instrument, the inlet was set to splitless injection. The injection port was set at a temperature of $280^{\circ} \mathrm{C}$. The column used was an Agilent HP-5MS (5\% phenyl methyl siloxane) open- 


\section{Supplementary Information}

capillary column with a $30 \mathrm{~m}$ length, $0.25 \mathrm{~cm}$ inner diameter, and stationary-phase thickness of $0.25 \mu \mathrm{m}$. The carrier gas was $\mathrm{H}_{2}$, set in constant flow mode at $2.2 \mathrm{~mL} / \mathrm{min}$ (a nominal head pressure of $14.30 \mathrm{psi}$, to give an average linear velocity of $60 \mathrm{~cm} / \mathrm{sec}$ ). The detector was set at $300{ }^{\circ} \mathrm{C}$, with an $\mathrm{H}_{2}$ flow of 50 $\mathrm{mL} / \mathrm{min}$, a compressed air flow of $450 \mathrm{~mL} / \mathrm{min}$, and no make-up gas. For the 5890/MS instrument, the injection port was set at a temperature of $250{ }^{\circ} \mathrm{C}$. The column used was a J\&W HP-5MS (5\% Phenyl methyl siloxane) open capillary column with an approximate length of $25 \mathrm{~m}, 0.25 \mathrm{~cm}$ inner diameter, and stationary-phase thickness of $0.25 \mu \mathrm{m}$. The GC used He as the carrier gas, set in constant flow mode at 1 $\mathrm{mL} / \mathrm{min}$. The detector was set at $280^{\circ} \mathrm{C}$.

For the analysis of DCiTG in an organic solvent such as $\mathrm{CH}_{2} \mathrm{Cl}_{2}$, the product, reactants, and crude reaction mixtures were analyzed using the following temperature program: $100^{\circ} \mathrm{C}$ ramped at $20^{\circ} \mathrm{C} / \mathrm{min}$ to a final temperature of $300^{\circ} \mathrm{C}$, then held at $300^{\circ} \mathrm{C}$ for three min. The integrator was started at $2.5 \mathrm{~min}$ and recorded signal to the end of the run. For the analysis of the NGS solvent, the integrator was started at $8.5 \mathrm{~min}$ and recorded the signal until the end of the run so that the much more intense signals from the Isopar solvent and the modifier alcohol were ignored.

\section{REFERENCES}

1. Leonard, R., Initial Flowsheet for the Next Generation CSSX Process in the MCU. Report for FY2010, ANL-LTR-NGCSSX-001, Argonne National Laboratory, 2010.

2. Peterson, R. A. Preparation of Simulated Waste Solutions for Solvent Extraction Testing, WSRS-RP-2000-00361, Westinghouse Savannah River Company, 2000. 